\title{
Introduksjonen av dreiekvernen i Sørvest-Norge
}

\section{Innledning}

Kvernsteiner, er det noe spennende, da? Tunge og uhåndterlige tar de opp stor plass i magasin rundt om i både Norge og Europa, ofte uten at noen har ofret en tanke på deres potensial som forskningsobjekter. Selv om de har vært et helt uunnværlig redskap for å forvandle korn til mel, og dermed spilt en avgjørende rolle i livberging og husholdningsøkonomi, har de ikke vært gjenstand for særlig stor interesse i arkeologisk forskning. De har ikke engang et eget oppslagsord i Norsk Arkeologisk Leksikon. I denne artikkelen vil jeg presentere de viktigste resultatene av et forskningsprosjekt om én type håndkvern - de eldste dreiekvernene i Sørvest-Norge, primært Rogaland, med vekt på klassifisering, råstoffbruk, utvinnings- og produksjonsteknikk samt kronologi. Dreiekvernen i sin enkleste form består av to sirkulære (ett par) kvernsteiner med hull i midten, plassert oppå hverandre (se figur 1). Den øre steinen dreies rundt, og kornet blir malt til mel mellom kvernsteinene.

Kvernsteiner er ikke bare «runde steiner med hull», de kan være en kilde til informasjon om ressursutnyttelse - hvilket råstoff man brukte til å lage dreiekverner. De kan gi informasjon om teknologi - hvordan man utvant råstoffet og laget kvernsteinene. Et nærmere studium gir den kronologiske rammen - hvor gammel dreiekvernen i Sørvest-Norge egentlig er. Når man vet hvilke(t) råstoff dreiekvernene ble laget av, kan man diskutere handel kontra lokal produksjon. Hvilken betydning hadde introduksjonen av dreiekvernen økonomisk og samfunnsmessig? Var for eksempel dreiekvernen allemannseie eller forbeholdt noen få? (Man skal kanskje heller si «allekvinnerseie», siden maling med håndkvern i alle kulturer i hele verden er kvinnearbeid med noen få unntak, som romerske legionærer på felttog og munker). Det er først når malingen flytter ut av den hjemlige sfære og inn i kvernhus, at den mannlige mølleren oppstår (se også Watts 2014:56). Den samfunnsmessige og økonomiske betydning av dreiekvernens bruk i Sørvest-Norge i eldre jernalder vil bare bli kortfattet berørt - det er et svært omfattende (om enn neglisjert) forskningsfelt som fortjener et eget studium. 

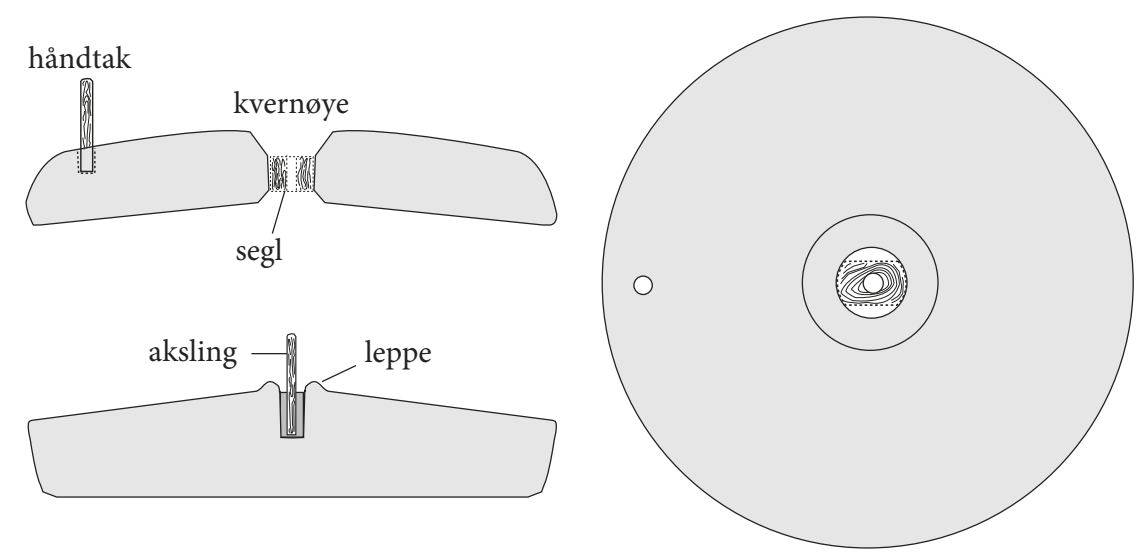

Figur1. Skjematisk fremstilling av dreiekvern. Illustrasjon: Timothy Anderson.

\section{Bakgrunn og problemstillinger}

Arkeologisk museum, Universitetet i Stavanger (Am, UiS) har den største samlingen av forhistoriske dreiekverner i Norge, med mer enn 150 kvernsteiner til dreiekverner eller fragmenter av slike, mye takket være Jan Petersens hustuftsundersøkelser på 1920- og 1930-tallet (Petersen 1933, 1936). Den store samlingen var grunnen til at museet ble invitert som partner i The Norwegian Millstone Landscape (2009-2013), et tverrvitenskapelig forskningsprosjekt initiert og ledet av Norges geologiske undersøkelse (NGU) ved Gurli Meyer, Tom Heldal og Tor Grenne. Prosjektets hovedfokus var kvernsteinsbruddenes landskap i et langtidsperspektiv, konsentrert om bruddene med granat- og staurolittglimmerskifer fra middelalderen og frem til tidlig 1900-tall. Målet var å identifisere geologiske, arkeologiske og historiske element i brudd-landskapene, tidsdybde og utviklingsmønster, analysere distribusjonen og bruken av kvernsteiner fra forskjellige brudd gjennom tidene og belyse kvernsteinsbruddenes viktige betydning historisk og kulturelt (Baug og Løland 2011; Heldal og Meyer 2011; Baug og Jansen 2014; Grenne, Meyer og Heldal 2014; Grenne mfl. 2014).

Formålet med delstudien ved Am, UiS var å analysere de forhistoriske dreiekvernene i samlingen, forløperne til kvernsteinene av granat- og staurolittglimmerskifer som var hovedfokus for Millstone-prosjektet. Fordi forhistoriske kvernsteiner ikke tidligere har vært studert i særlig grad i Norge, er dette det første større arbeid om denne gjenstandskategorien (Hauken og Anderson 2014a.). Studien ble konsentrert om noen helt grunnleggende aspekter. Vi ønsket å få svar på om det var mulig å skjelne ulike typer, og om de i tilfelle var kronologisk relevante, hvilke bergarter som ble brukt som råstoff, hvor råstoffet kom fra, hvordan kvernsteinene ble laget, og når dreiekvernen ble tatt i bruk.

Gjenstandsmaterialet brukt til analysen består av 85 kvernsteiner fra 27 lokaliteter i Rogaland. De ble valgt ut fordi de ble vurdert som sikre kronologiske kontekster. Med ett unntak kommer alle fra hustuftlokaliteter (gårdsanlegg) (figur 2). Med to unntak (Hauken og Anderson 2014a:17, 28-29) er alle de undersøkte dreiekvernene funnet i sekundært leie, gjenbrukt som byggemateriale i steinvegger, i stolpehull, i hellelegninger eller som underlag for stolper som ikke var nedgravd. 


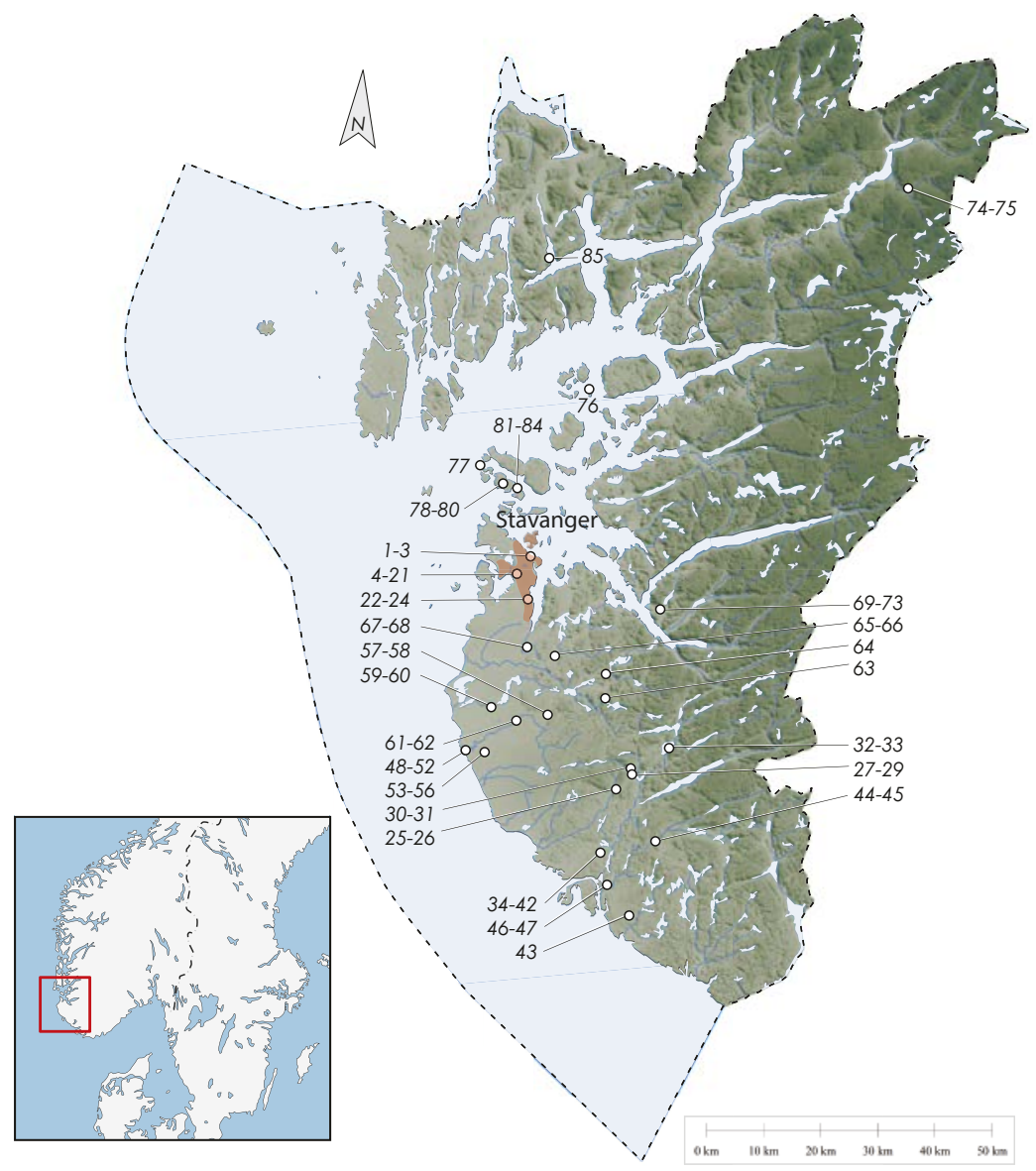

Figur 2. Kart over Rogaland med de undersøkte kvernsteinslokalitetene markert. Tallene refererer til katalognumrene i Hauken og Anderson (2014a). Kartgrunnlag: Statens kartverk. Kart: Theo Gil, Am, UiS.

Helt $\mathrm{i}$ begynnelsen av arbeidet ble det laget et registreringsskjema for dreiekvernene for å sikre en enhetlig dokumentasjon av hver enkelt stein (Hauken og Anderson 2014b). Alle steiner ble fotografert på begge sider, og tverrsnitt av steinene ble tegnet før klassifikasjonsarbeidet tok til.

\section{Forskningshistorie}

Lite var kjent om jernalderens dreiekverner i Sørvest-Norge, som i Norge for øvrig, da The Norwegian Millstone Landscape startet. Det eneste tidligere arbeidet om råstoffbruk er en kort artikkel om bergartene brukt til dreiekvernene på Ullandhaug i Stavanger (Dahl 1986). I sin omtale av dreiekvernen i Oseberg-funnet sier Sigurd Grieg, med henvisning til Sophus 
Müller (1907), at dreiekvernen i Norden går tilbake til romersk jernalder (Grieg 1928:164). Han nevner ett norsk funn som viser at dreiekverner var brukt i Norge i eldre jernalder - et gravfunn fra Rygg, Etne kommune, Hordaland, datert til folkevandringstid (B7232). Grieg siterer også Müllers antagelse om at dreiekvernen «først kom i Brug hos de klassiske Folk ned imod Chr.F.s Tid, og at den med den romerske Kultur blev udbredt over Landene» (Müller 1907:148). Påstanden om at dreiekvernen skulle være en romersk oppfinnelse ble tilbakevist allerede av Gudmund Hatt (1930:103, note 1), mens forestillingen om at spredningen til Skandinavia skyldes romersk kulturpåvirkning, har vist seg betydelig mer seiglivet (se for eksempel Zachrisson 2014). Jan Petersen behandlet dreiekvernen i Vikingtidens redskaper (1951:438-440), og var - naturlig nok - fremst interessert i kvernsteinsfunn i graver fra vikingtid. Han diskuterer kortfattet kvernsteinenes kronologi, og nevner et gammelt funn fra Store-Dal hvor flere fragmenter av dreiekverner var brukt i konstruksjonen av en gravrøys, datert til 4. århundre (Petersen 1916:9-10, Plansje 1:figur 11-13, Plansje II). Petersen kunne dermed slå fast at dreiekvernen var i bruk i Norge før 400 e.Kr., men han overså den virkelige betydningen av funnet - fragmentene må være eldre enn graven fra 4. århundre.

Bjørn Myhre skrev i 1992 at «vi antar at dreiekverner erstattet skubbekverner omkr. 300 e.Kr.», basert på funnmaterialet fra Ullandhaug (Myhre 1992:48). Ti år senere, basert på det samme materialet, skyver han i en billedtekst tidspunktet tilbake til $200-300$ e.Kr. (Myhre og Øye 2002:144), og postulerer også samtidig bruk av skubbe- og dreiekverner. I brødteksten er skiftet fra skubbe- til dreiekvern plassert i uspesifisert romertid, og ingen samtidig bruk er antatt (Myhre og Øye 2002:143).

\section{Grunnleggende kvernsteinsterminologi}

En dreiekvern består av to sirkulære, tilhogde steiner, 35-45 cm i diameter og 5-15 cm tykke (jr. figur 1). Underliggeren/understeinen ligger fast med maleflaten vendt opp. Ovenpå underliggeren ligger en roterende overligger/overstein som har maleflaten vendt ned. Begge steiner har et hull i midten, et kvernøye. Akslingen er montert i underliggerens kvernøye og går gjennom overliggerens kvernøye. Underliggeren har en konveks maleflate og som oftest en grovt tilhogd underside. Leppen på underliggeren er et resultat av slitasje, og kan dermed være mer eller mindre fremtredende. Kvernøyet kan være helt eller delvis gjennomgående («blinde»); «blinde» kvernøyer forekommer ikke på kvernsteiner fra middelalder og moderne tid. Overliggeren har en konkav maleflate med gjennomgående kvernøye, utvidet på oversiden til en vid trakt. Kvernen blir kontinuerlig matet med korn i trakten, og kornene blir ført ned til maleflatene gjennom trakten og kvernøyet av vibrasjonene som oppstår når overliggeren dreies rundt. Vanligvis er det én kvinne som maler, men det finnes historiske belegg for at to kvinner har dreiet én kvern (Peacock 2013:74-75, figur 4:10).

Tre forskjellige innretninger for å dreie kvernsteinen er identifisert. Den første består av et vertikalt hull for et håndtak (dreiepinnehull) (figur 3a). Den andre, som er den vanligste, har ikke levnet noen synlige spor på steinen, og har da sannsynligvis bestått av et rep/belte av plantefibre eller ugarvet lær, med en løkke for håndtaket (figur 3b). Den tredje består av et radiært spor (figur 3c), slik som på kvernsteinen fra Oseberg-funnet (Grieg 1928:165, figur 102). Dette indikerer et mer forseggjort håndtak som spente over steinens radius og var festet til akslingen. Jernbelter, som finnes på en type britiske steiner (Green 2011:125, figur 5h) synes ikke å ha vært brukt i Norge, for det finnes ikke spor av jernkorrosjon på noen av steinene. 

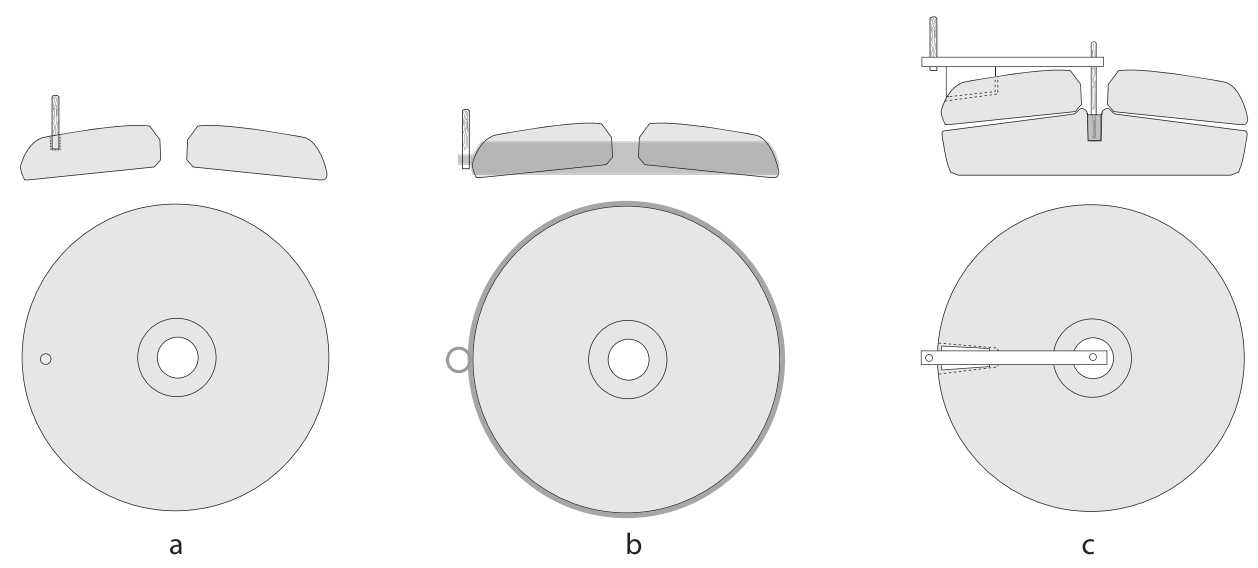

Figur 3. De tre identifiserte dreiemekanismene: a) vertikalt dreiepinnehull, b) uten dreiepinnehull, med rep/belte og løkke for dreiepinnen, c) med radicert spor. Illustrasjon:

Timothy Anderson.

Seglet er en viktig komponent på både håndkverner og store møllesteiner. I sin enkleste form består den av en gjennomboret trekloss, kilt ned i kvernøyet på overliggeren. Akslingen løper gjennom hullet i seglet og sørger for at kvernen roterer jevnt. En mer avansert form for segl gjør det mulig å justere avstanden mellom over- og underliggeren. På overliggerens maleflate finner man da to rombiske innskjæringer rett overfor hverandre ved kvernøyet, som toppstykket på akslingen passer inn i. Akslingen kan justeres i høyden. I samlingen ved Am, UiS finnes denne type segl bare på kvernsteiner fra middelalder. Det finnes foreløpig ingen belegg for at segl ble brukt i eldre jernalder i Rogaland; seglet er altså et viktig element for å skille forhistoriske kvernsteiner fra steiner fra middelalder og moderne tid. I stedet for segl er det meget mulig at dreiekvernene fra eldre jernalder bare var utstyrt med en aksling av tre, godt kilt fast i øyet på underliggeren og kanskje med en kile i øyet på overliggeren for å få en stabil rotasjon (jf. Alonso mfl. 2014:figur 6a).

Maleflatene på over- og underligger måtte bearbeides slik at de passet sammen. Det må være nok plass i området rundt kvernøyet for at kornene skal kunne føres ut mot periferien på maleflatene, hvor selve malingen foregår, og maleflatene må også passe sammen (Jørgensen 2002:189-190). Dette er en sterk indikasjon på at kvernhogging var et spesialisert håndverk. Etter en tids bruk ble maleflatene slitt og måtte skjerpes opp. Dette var et arbeid som ikke krevde spesiell ekspertise, siden det ble gjort som prikkhogging, og en hvilken som helst stein av kvartsitt med passe tyngde kunne brukes.

Sammenlignet med skubbekvernen er en dreiekvern et effektivt og tidsbesparende redskap for å male korn til mel. Skubbekvernen består også av to deler, en avlang underligger med konkav overside som kornet ligger på. Med en løper som gnis frem og tilbake mot kornet, blir kornet omsider til mel, men med mange stopp i arbeidsprosessen for å holde kornet på plass og for å fylle på mer korn. Å male mel på skubbekvern er hardt arbeid som tar lang tid, å male den samme mengden mel på dreiekvern kan gå ti-tolv ganger så fort (Wefers 2011:67 med videre henvisninger; Peacock 2013:127-129). Dreiekvernen er også 
enklere å male med. Når rotasjonen først er kommet skikkelig i gang, fungerer kornene som kulene i et kulelager, slik at det er mer om å gjøre å holde rotasjonen i gang enn å bruke rå muskelkraft (men det er slitsomt, uansett), og man trenger ikke å stoppe rotasjonen for å fylle på korn. Å male korn til mel er en prosess med flere trinn, hvor sålding også inngår (Alonso mfl. 2014:19-24). Siden vi ikke vet hvordan man tresket korn i forhistorisk tid, må vi anta at i hvert fall det siste trinnet - å skille agnene fra kornet - skjedde gjennom en første grovmaling med påfølgende sålding.

\section{Klassifisering}

For å gjøre gjenstandsmaterialet mer oversiktlig ble kvernsteinene delt inn i tre forskjellige typer overliggere og tre forskjellige typer underliggere. Etter at klassifiseringen var ferdig, var spørsmålet om typene var kronologisk relevante.

Klassifiseringen hadde som utgangspunkt en detaljert studie av kvernsteiner fra bosetningene Vorbasse og Nørre Snede på Jylland, utført av Anne Bloch Jørgensen (1990). Hun identifiserte to hovedtyper over- og underliggere med undertyper (Jørgensen 2002:figur 3). Denne typeinndelningen viste seg til en viss grad også å fungere på det studerte norske materialet, selv om det var avvik i proporsjonene (for eksempel forholdet tykkelse/diameter). Alle de studerte norske kvernsteinene er tynnere enn de danske og har en større

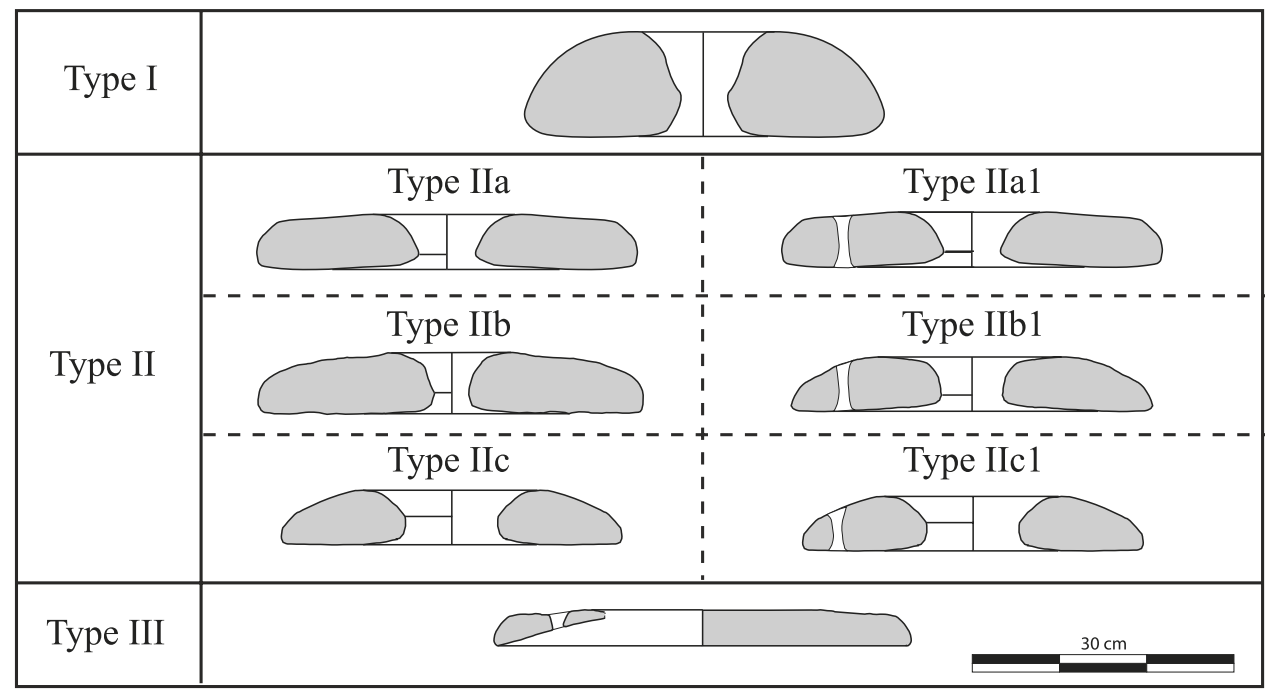

Figur 4. Typeinndelingen av overliggerne fra Rogaland. Type I: tykk, kuppelformet uten dreiepinnehull. Type II er inndelt i tre undertyper, $a-c$, hver med sin variant-uten eller med dreiepinnehull (a1-c1). Type IIa: steil ytterkant som er rett eller svakt krum, markert overgang til flat eller svakt konveks overside. Type IIb: skrå ytterkant som er krum eller konveks, uten markert overgang til konveks overside. Type IIc: kort, krum ytterkant, svakt markert overgang til konveks overside. Type III: overliggere av granatglimmerskifer. Illustrasjon: Timothy Anderson. 
variasjon i diameter, slik at de norske kvernsteinene er typebestemt kun på morfologiske kriterier, det vil si omriss, formen på ytterkanten og på oversiden.

Overliggerne (figur 4) betegnes med romertall, type I-III. Type I er en tykk, kuppelformet stein uten dreiepinnehull. Type II kan inndeles i tre undertyper, a-c, hver med sin variant - uten eller med dreiepinnehull (a1-c1). Type IIa har steil, rett eller svakt krum kant og markert overgang til en flat eller svakt konveks overside. Type IIb («smultringen») har skrå, krum eller konveks kant uten markert overgang til en konveks overside. Type IIc har en kort, krum kant og en konveks overside. Overgangen kant/overside er bare svakt markert. Felles for typene I og II er den nesten helt horisontale eller svakt konkave maleflaten med fravær av seglmerker. Type III betegner steiner av granatglimmerskifer. De finnes ikke i det danske materialet som Bloch Jørgensen behandlet. Type III er ikke inndelt i undertyper, fordi steinene i samlingen ved Am, UiS (alle fra middelalderkontekster) er for fragmenterte til at det skulle være mulig, men de har både dreiepinnehull, konkav maleflate og seglmerker.

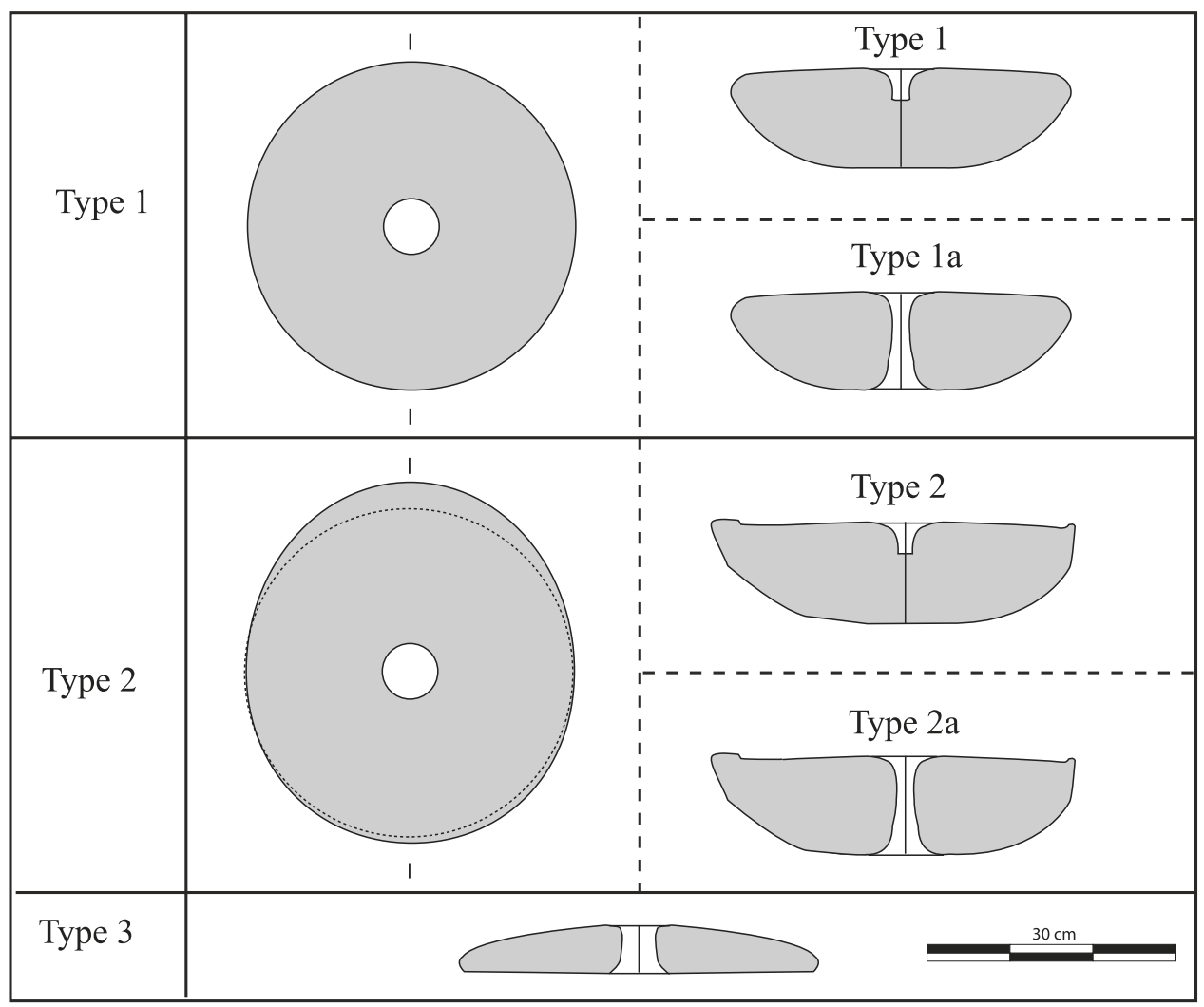

Figur 5. Typeinndelingen av underliggerne fra Rogaland. Type 1: sirkulcert omriss, blindt kvernøye, la med gjennomgående kvernøye. Type 2: ovalt omriss, blindt kvernøye, 2 a med gjennomgående kvernøye. Type 3: underliggere av granatglimmerskifer. Illustrasjon: Timothy Anderson. 
Underliggerne betegnes med arabiske tall etter omrisset på maleflaten - sirkulært, type 1, eller ovalt, type 2, (figur 5) og med variantene blinde eller gjennomgående kvernøyne (1a, 2a). Type 3 er underliggere av granatglimmerskifer, som alltid har gjennomgående kvernøye og konveks maleflate. Typene 1 og 2 derimot har nesten horisontale eller bare svakt konvekse maleflater. Noen av underliggerne av disse to typene er meget tunge, en sterk indikasjon på at de hadde en permanent plass i huset. Underliggeren fra tuft 1 på Birkeland av Eige store, Eigersund kommune, er et eksempel på dette (Petersen 1933:5-7; Hauken og Anderson 2014a:17-19). Den var så tung at den ikke ble tatt inn til museet, men ble liggende igjen hvor den ble funnet, på den langsgående sentrale aksen i tuften, nær et lite ildsted (Hauken og Anderson 2014a:figur 12-13). En slik fast plass krever at kvernen også hadde en permanent melfanger. Den var sannsynligvis av tørket leire, som kunne gi en jevn overflate uten skjøter rundt underliggeren, men dette er en struktur som hittil ikke er identifisert. De fleste underliggere er imidlertid av mer bærbar størrelse, og da kan melfangeren ha vært et stort skinn som underliggeren ble plassert på.

\section{Råstoff og utvinningsteknikker}

Hoveddelen av Rogalands grunnfjell stammer fra prekambrium og inkluderer gneis og granitt (figur 6) samt et stort kompleks av anortositt og gabbro i sydøst, Eigersundfeltet (det skråskraverte området på figuren). Fyllitt og glimmerskifer, lokalt med granater, finnes i Stavanger-området og nordover. Det kaledonske skyvedekket, som overleirer fyllitten og glimmerskiferen, inneholder gneis og granitt. Låg-Jæren domineres av kvartære løsmasser med mye løsblokker, etterlatt ved innlandsisens tilbaketrekning for ca. 12000 år siden. Det finnes fremdeles områder med mye løsblokker i dagen, som kan gi et visst inntrykk av det forhistoriske landskapet.

Tabell 1 viser bergartene som ble benyttet til kvernsteinsproduksjon i Rogaland. Bortsett fra eksemplarene av granatglimmerskifer (tre fra Hyllestad i Sogn og Fjordane og fem fra Saltdal i Nordland) er alle dreiekvernene av lokale bergarter. Gneis og glimmergneis var foretrukne råstoff; begge er såpass myke at de kunne bearbeides, men likevel så harde at det kunne males korn med dem. $25 \%$ av underliggerne er av granitt, sannsynligvis fordi den er hard og slitesterk.

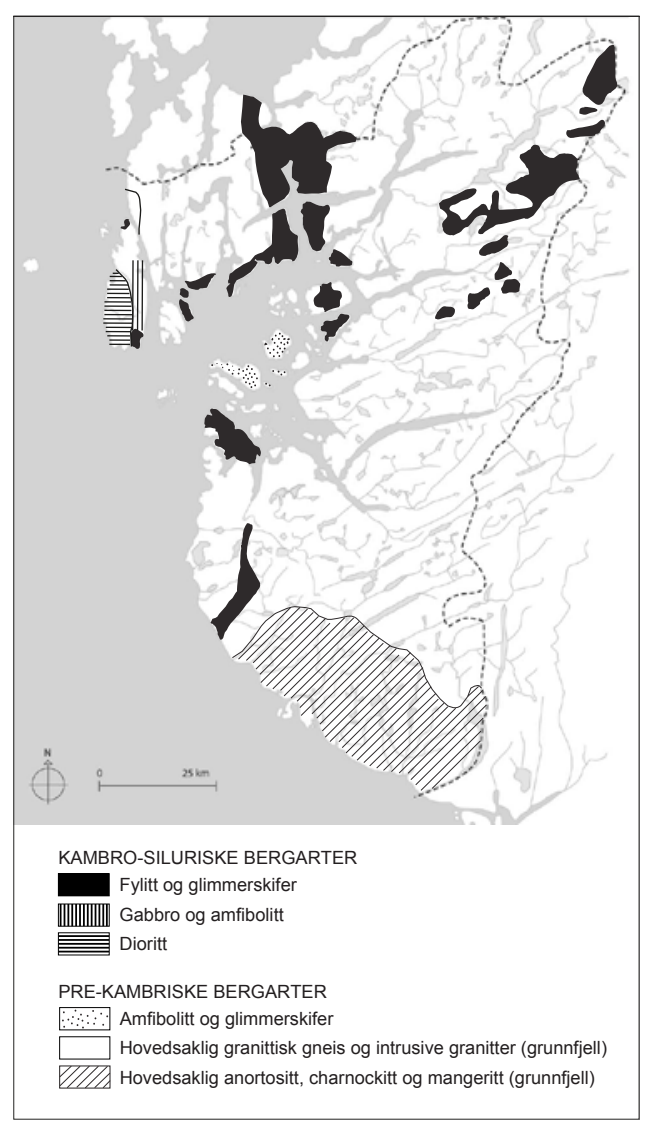

Figur 6. Forenklet berggrunnskart over Rogaland med de vanligste bergartene. Kartgrunnlag: Am, UiS. Kart: Øystein. J. Jansen. Digitalisering: Timothy Anderson. 
Hvis vi ser nærmere på to områder i Rogaland, Stavanger-området i nord og BjerkreimEigersund-området i sør, kan vi se at bergartene som ble brukt til kvernsteiner, reflekterer de lokale bergartene (tabell 2, sammenlign figur 6). Gneis og glimmergneis er vanlige i Stavanger-området, mens granitt er mer karakteristisk for Bjerkreim-Eigersund-området, i tillegg til gabbro og anortositt.

Tabell 1. Bergartene brukt til kvernsteinene i Rogaland med angivelse av typene. Avviket mellom totalsummen og summen av over- og underliggere skyldes et fragment av dreiekvern som ikke kunne bestemmes som verken det ene eller andre. (Hy=Hyllestad. Sa=Saltdal).

\begin{tabular}{|c|c|c|c|c|c|c|}
\hline Bergart & Antall steiner & $\%$ & Type overliggere & $\mathrm{n}$ & Type underliggere & $n$ \\
\hline Gneis & 20 & 23 & I, Ila1, Ilb, Ilb1 & 13 & 1,2 & 6 \\
\hline Glimmergneis & 16 & 19 & Ila, Ilb, Ilc & 14 & $2 a$ & 2 \\
\hline Granitt & 12 & 14 & Ila, Ilb, Ilc & 6 & 1, 1a, 2 & 6 \\
\hline Granatglimmerskifer & 11 (3 Hy, 5 Sa) & 13 & $\|c 1\| \|$, & 8 & 3 & 3 \\
\hline Glimmerskifer & 5 & 6 & $\|l b\| c 1$, & 2 & 1.2 & 3 \\
\hline Øyegneis & 3 & 3 & Ila, Ilb & 3 & - & - \\
\hline Gabbro & 3 & 3 & Ila, Ilb, ubest. & 3 & - & - \\
\hline Anortositt & 2 & 2 & $\|\mathrm{l},\| \mathrm{b}$ & 2 & - & - \\
\hline Glimmergneis/glimmerskifer & 2 & 2 & I, Illb & 2 & - & - \\
\hline Syenitt (?) & 2 & 2 & Ila & 2 & - & - \\
\hline Granodiorittisk gneis & 2 & 2 & - & - & 1a, 2a & 2 \\
\hline Protomylonitt & 2 & 2 & emne; ubest. & 2 & - & - \\
\hline Granittisk gneis & 1 & 1 & - & - & 1a & 1 \\
\hline Ubestemt & 4 & 5 & Ila, ubest. & 3 & 2 & 1 \\
\hline SUM & 85 & & & 60 & & 24 \\
\hline
\end{tabular}

Tabell 2. Bergartene brukt til kvernsteiner i hhv. Bjerkreim-Eigersund-området (nr. 25-43 på figur 2) og Stavanger-området (nr. 4-24 på figur 2). Forskjellen i berggrunnen $i$ de to områdene gienspeiles $i$ kvernsteinenes råstoff.

\begin{tabular}{|l|c|c|c|c|}
\hline & \multicolumn{2}{|c|}{ Bjerkreim \& Eigersund k. $\mathbf{n}=23$} & \multicolumn{2}{c|}{ Stavanger k. $\mathbf{n}=24$} \\
\hline Bergart & antall & $\%$ & antall & 10 \\
\hline Gneis & 2 & 9 & 5 & 21 \\
\hline Glimmergneis & 1 & 4 & 1 & 4 \\
\hline Granitt & 10 & 43 & 3 & 13 \\
\hline Granatglimmerskifer & 1 & 4 & - & - \\
\hline Gabbroid bergart & 3 & 13 & - & - \\
\hline Anortositt & 2 & 9 & - & 8 \\
\hline Syenitt (?) & 2 & 9 & 2 & 8 \\
\hline Protomylonitt & - & - & 2 & 4 \\
\hline Glimmerskifer & - & 9 & 1 & \\
\hline Ubestemt & 2 & - & & \\
\hline
\end{tabular}


De fleste kvernsteinene ble hogd av løsblokker hentet på markoverflaten. Et mindre antall ble hogd fra naturlig dannede heller, vanligvis glimmergneis. Graden av tilhogging er varierende. Noen steiner er lite forseggjort ut over tilhoggingen til sirkulær form og kvernøye, mens andre har tilnærmet perfekt sirkelform, omhyggelig bearbeidet. Som nevnt tidligere er det mulig at kvernsteinshogging var et spesialisert handverk. Det åpner jo også for muligheten at det var en lokal handelsvare, selv om det vil være vanskelig å føre bevis for det, siden råstoffet er løsblokker. Råstoffet i kvernsteinene sammenfaller med de lokale bergartene, men kan naturlig nok ikke stedfestes nærmere. Det stiller seg helt annerledes med råstoff fra fast fjell, slik som granatglimmerskiferen, som kan proveniensbestemmes. Utvinning fra fast fjell i eldre jernalder er helt ukjent i Rogaland, men er heller ikke undersøkt nærmere.

\section{Kronologi}

Det største antallet kvernsteiner stammer fra Petersens hustuftundersøkelser, som er datert på tradisjonelt vis ved hjelp av gjenstander, særlig keramikk, til yngste romertid (C3) og folkevandringstid. I løpet av studien viste det seg at utgravningene på Forsandmoen 19801990 (Løken 1996 med videre henvisninger, 2001; Hauken og Anderson 2014a:30-32; Løken i trykk) ble avgjørende for forståelsen av de tidligste kvernsteinenes kronologi, takket være de mange C14-daterte hustuftene. Figur 7 er et forenklet kart over den sørvestlige delen av bosetningen der kvernsteinene ble funnet. Samlingen består av ni fragmenter av fem dreiekverner: to av type I, en av type IIal og to av type IIb.

Fordi alle kvernsteinene/fragmentene ble funnet i sekundært leie, bl.a. i stolpehull som stolpefundament, er kontekstene og dateringene å betrakte som terminus ante quem (latin: grense før hvilken, forkortet t.a.q.), det vil si at kvernsteinene er eldre enn husene de ble funnet i. De kalibrerte C14-dateringene er presentert i figur 8 og tabell 3. Kalibreringen er OxCal 4.2.4, gjengitt med $68 \%$ sannsynlighet, $1 \sigma$. (95,4 \% sannsynlighet, $2 \sigma$, forteller i grunnen bare at de daterte strukturene er fra eldre jernalder, med stor overlapping.)

Den eldste dreiekvernen fra Forsandmoen og Rogaland er en type I-overligger fra bygning 10a. Hvis de to dateringene fra sentralildstedene antas å representere en samtidighet for bruken av huset (single event), er dateringen 135-248 e.Kr. (T-6395, T-5903). Det tyder på at dreiekvernen ble tatt $\mathrm{i}$ bruk klart tidligere enn tidligere antatt, allerede $\mathrm{i}$ andre halvpart av 2. århundre eller rundt 200. Den eldste dreiekvernen på Vorbasse er datert til 150-180 e.Kr. (Jørgensen 1990:48). Den andre type I-kvernen på Forsandmoen ble funnet $\mathrm{i}$ to deler - den ene i bygning 157 og den andre i bygning 158, og må følgelig være eldre enn begge disse (se tabell 3). Kvernen ble sannsynligvis brukt til sitt opprinnelige formål (å male mel) i bygning 156, datert til 179-382 e.Kr. (T-8629). Bygning 155, datert til 87-323 e.Kr. (T-8716), gir eldste dateringsgrense for bygning 156; de ligger så tett ved hverandre at de ikke kan ha stått samtidig. Bygningene øverst i sekvensen, 158 og 157, har vide dateringer, delvis overlappende, 158 fra 80-316 e.Kr. (T-8715) og 237-420 e.Kr. (T-8694), 157 fra 138-330 e.Kr. (T-8693) og 254-528 e.Kr. (T-8714). En Bayes-modell ${ }^{1}$ for dateringene, der 155 er eldre enn 156, som i sin tur er eldre enn 158 og med 157 som den yngste bygningen, gir en dateringsramme til 203-314 e.Kr. (68 \% sannsynlighet) for bygning 156. 


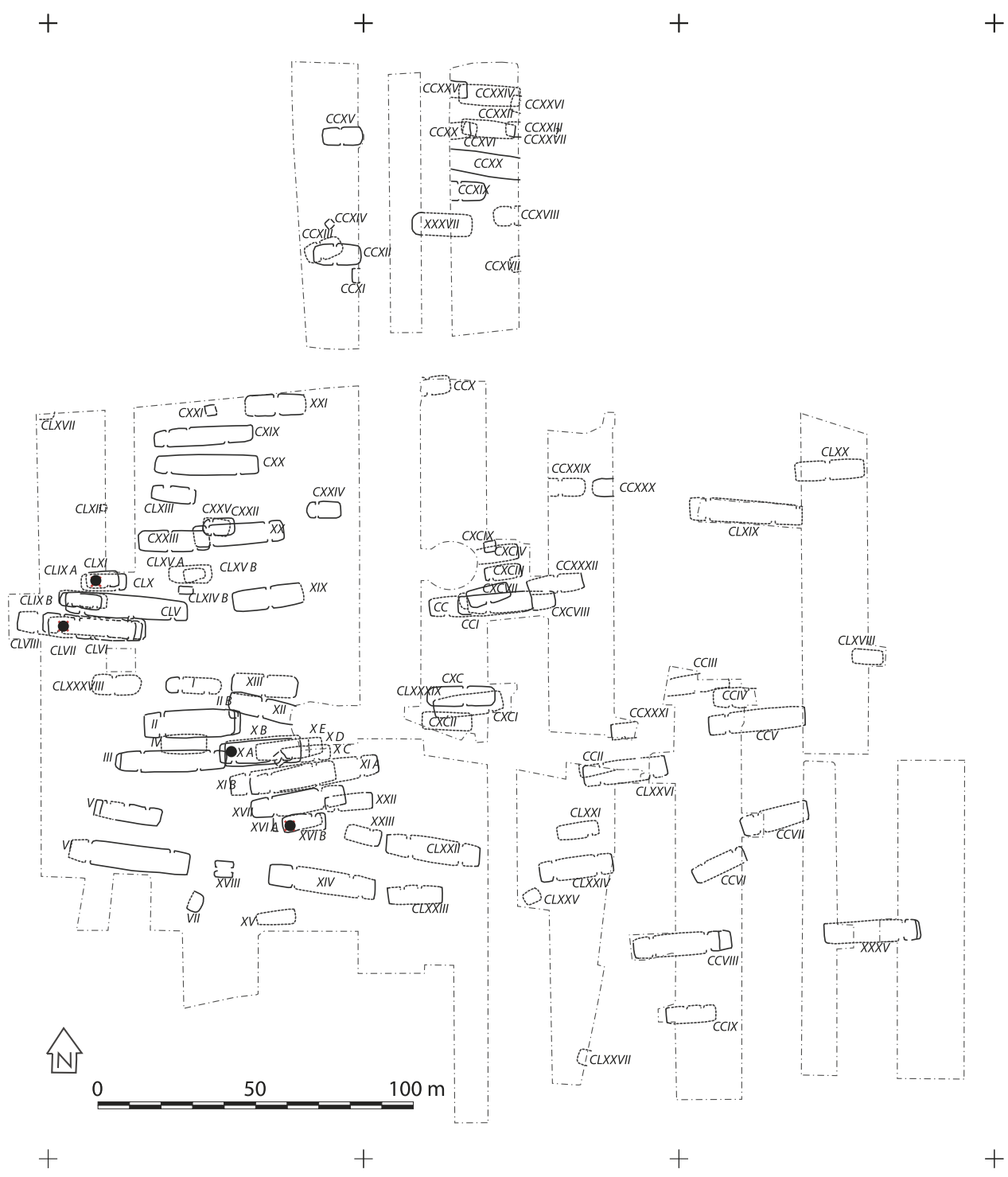

Figur 7. Kart over den sørvestlige delen av bosetningen på Forsandmoen. Bygninger med kvernsteinsfunn er markert med sorte prikker. Bygning CLXXX (180) ligger ca. $700 \mathrm{~m}$ sørøst for bygning $X X X V$, i en mindre samling bygninger. Kartgrunnlag: Forsandprosjektet. Kart: Timothy Anderson. 


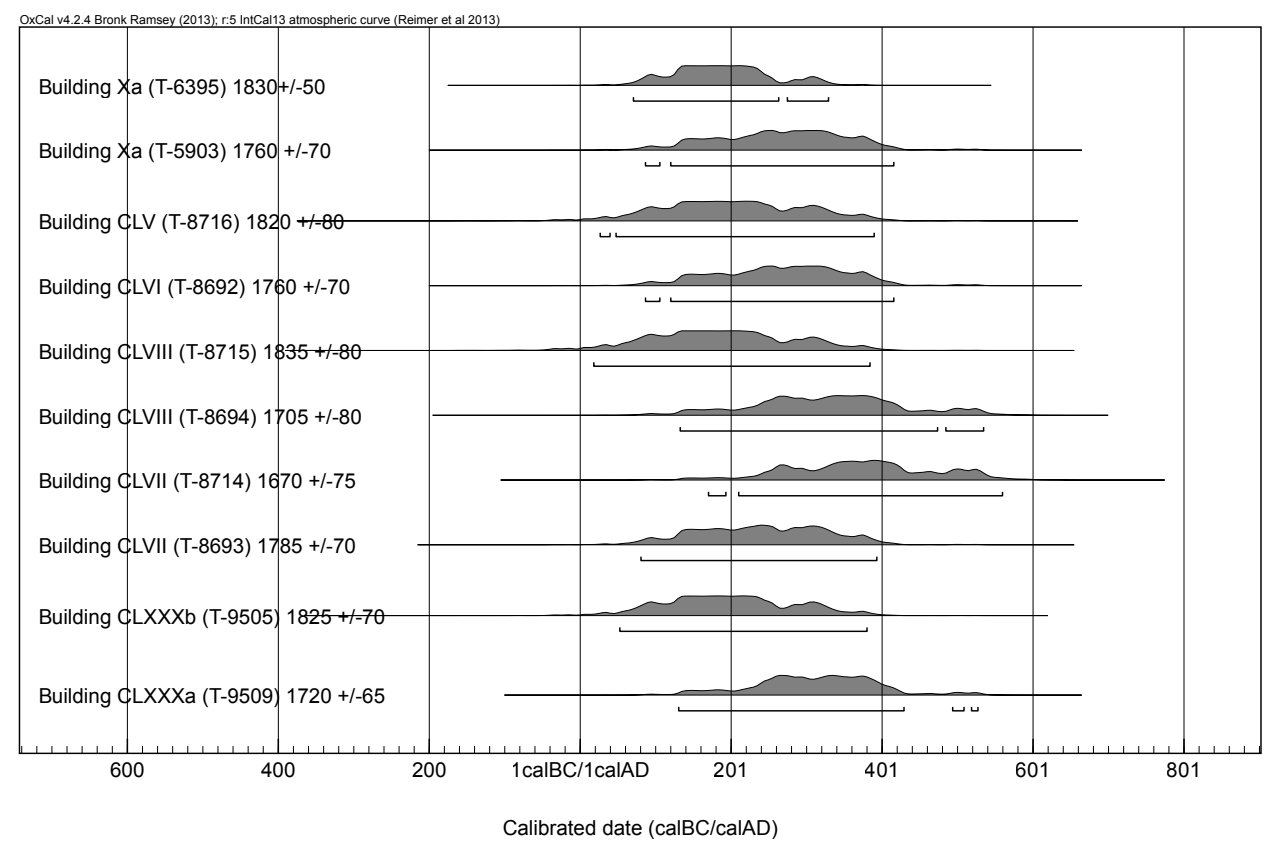

Figur 8. C14-dateringene fra bygninger med kvernsteinsfunn på Forsandmoen omtalt i teksten. Analysert og kalibrert gjennom OxCal 4.2 Bronk Ramsey 2013 (Reimer mfl. 2013).

Tabell 3. Tabellarisk fremstilling av C14-dateringene på figur 8. Bygningene ble under utgravningen betegnet med romerske tall; $i$ den løpende teksten er de konvertert til arabiske tall for à lette lesingen.

\begin{tabular}{|l|c|c|c|c|c|}
\hline Hus nr. & Materiale & Lab.ref. & Datering før nåtid & $\begin{array}{c}\text { Kalibrert alder } \\
\text { e.Kr. 95.4\% } \\
\text { sannsynlighet }\end{array}$ & $\begin{array}{c}\text { Kalibrert alder } \\
\text { e.Kr. 68,2\% } \\
\text { sannsynlighet }\end{array}$ \\
\hline Xa (10 a) & bjørk & T-6395 & $1830+/-50$ & $71-330$ & $125-245$ \\
\hline Xa (10a) & bjørk/or & T-5903 & $1760+/-70$ & $87-416$ & $179-382$ \\
\hline CLV (155) & bjørk & T-8716 & $1820+/-80$ & $27-390$ & $87-323$ \\
\hline CLVI (156) & bjørk & T-8692 & $1760+/-70$ & $87-416$ & $179-382$ \\
\hline CLVIII (158) & bjørk & T-8715 & $1835+/-80$ & $19-385$ & $80-316$ \\
\hline CLVIII (158) & bjørk & T-8694 & $1705+/-80$ & $133-535$ & $237-420$ \\
\hline CLVII (157) & bjørk & T-8693 & $1785+/-70$ & $81-394$ & $138-330$ \\
\hline CLVII (157) & bjørk & T-8714 & $1670+/-75$ & $171-560$ & $254-528$ \\
\hline CLXXXa (180a) & bjørk/or & T-9509 & $1720+/-65$ & $131-528$ & $247-391$ \\
\hline CLXXXb (180b) & bjørk & T-9505 & $1825+/-70$ & $53-381$ & $87-318$ \\
\hline
\end{tabular}


Den eldste kvernsteinen av type IIa, i dette tilfellet med dreiepinnehull, er også fra Forsandmoen, fra bygning CLXXX (180), som har to faser. Dateringene er ganske vide, men ligger statistisk mellom 2. og 4. århundre e.Kr. (T-9505, T-9509).

Den eldste kvernsteinen av type IIb er fra Gausel (Børsheim og Soltvedt 2002:136), funnet som fragmenter $i$ et stolpehull i en bygning datert til 330-470 e.Kr., som gir t.a.q. 330 e.Kr. som den tidligste dateringen for type IIb.

Den eldste dateringen for type IIc er fra Ullandhaug, med t.a.q. ca. 350 e.Kr. (Hauken og Anderson 2014a:77, 84). Den diakrone fremstillingen i figur 9 av overliggerne i eldre jernalder er ordnet etter type, med C14-daterte kvernsteiner i lysegrått. Det kronologiske forholdet mellom overliggere med og uten dreiepinnehull er uklart. Ut fra det foreliggende materialet ser det ikke ut til at det har vært noen utvikling fra overliggere uten dreiepinnehull til overliggere med dreiepinnehull. Fremstillingen viser imidlertid at typeinndelingen til en viss grad er kronologisk relevant - type I er den eldste, type IIa og IIb er omtrent samtidige, mens type IIc er den eneste som fortsatt er i bruk i yngre jernalder. Bosetningssporene fra yngre jernalder er få (se Bjørdal 2016:figur 1), og det er ikke funnet kvernsteiner fra noen av dem, bortsett fra på Hove i Sandnes kommune, hvor to deler av samme kvernstein er brukt som fundament $\mathrm{i}$ hver sitt stolpehull i en bygning fra merovingertid/vikingtid (Even Bjørdal, personlig kommunikasjon 2018). Det finnes to kvernsteiner av type IIa1 fra en middelalder-kontekst (Hauken og Anderson 2014a:19, cat.35 og 36), men de er sannsynligvis gjenbrukt som byggemateriale, og stammer opprinnelig fra bygningene fra folkevandringstid på samme lokalitet.

Den diakrone fremstillingen av underliggerne viser ingen kronologisk forskjell mellom typene, men en lengre brukstid for underliggerne med gjennomgående kvernøye (figur 10).

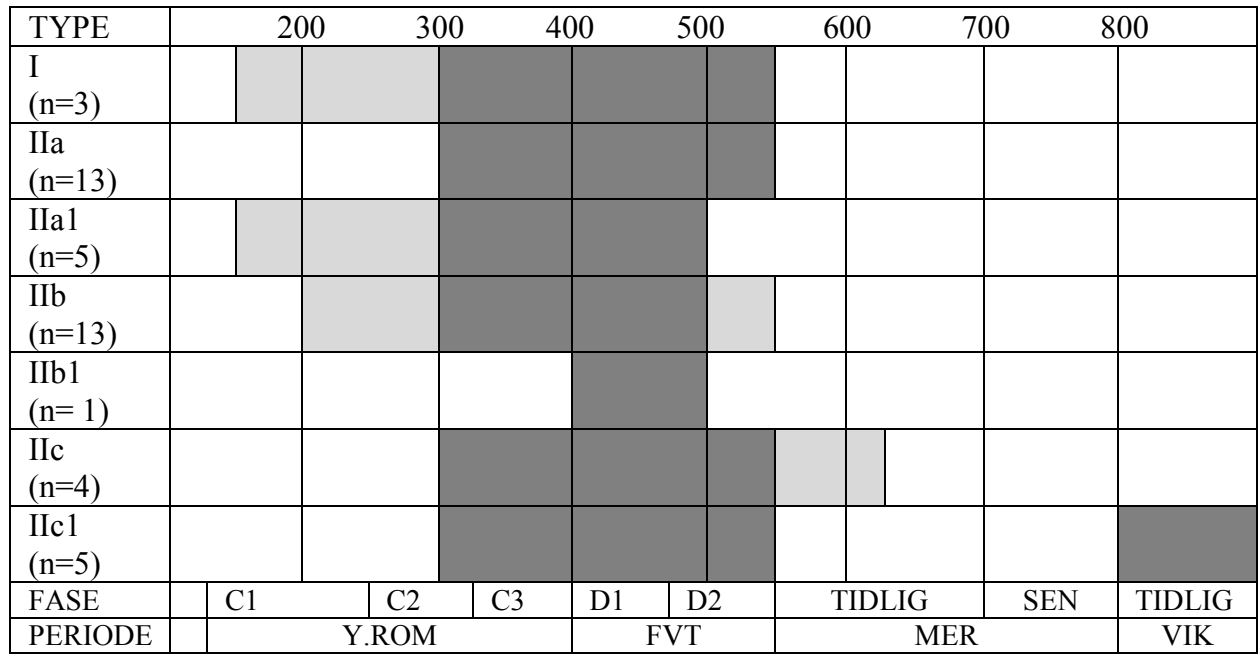

Figur 9. Overliggernes kronologiske plassering. C14-daterte kontekster er markert med lysegrått. Y.ROM: yngre romertid, FVT: folkevandringstid, MER: merovingertid, VIK: vikingtid. 


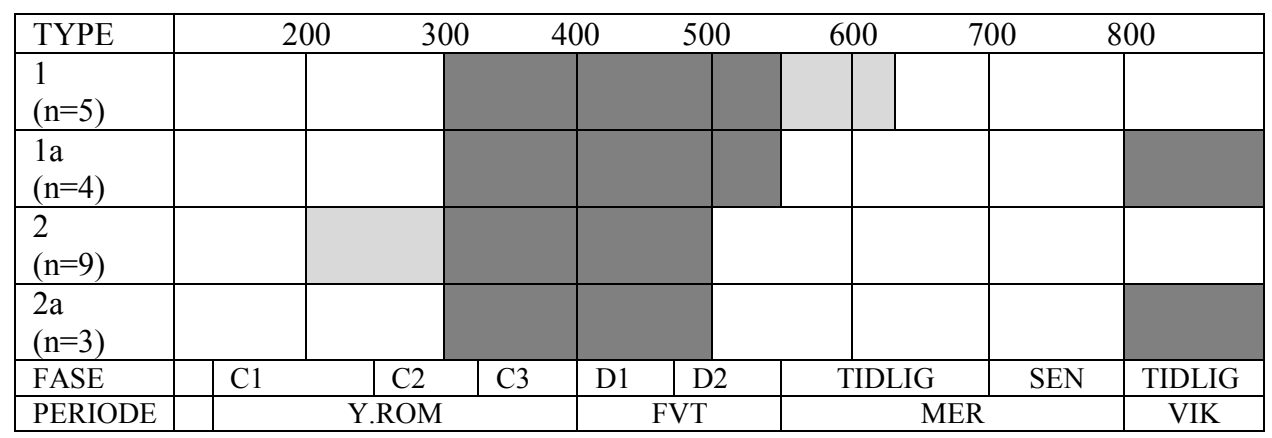

Figur 10. Underliggernes kronologiske plassering. C14-daterte kontekster er markert med lysegrått. Y.ROM: yngre romertid, FVT: folkevandringstid, MER: merovingertid, VIK: vikingtid.

Hvorfor det tok så lang tid før dreiekvernen slo igjennom i Skandinavia, minst 500-600 år sammenlignet med naboområdene i Europa, er et helt åpent spørsmål. De tidligste dreiekvernene i England, Tyskland og Polen dateres fra 5. til 3. århundre f.Kr. (Peacock og Cutler 2011:79; Wefers 2011:figur 2; Peacock 2013:58, 68-69). I de to første århundrene etter Kr. var de allment forekommende i disse områdene, slik at skandinavene neppe kan ha vært uvitende om dreiekvernens eksistens. Müller (1907:148) var helt overbevist om at dreiekvernen kom til Skandinavia fra Romerriket. Også i senere tid er det foreslått at dreiekvernen kom til Skandinavia gjennom romersk innflytelse (Zachrisson 2004:153; Bergström 2007:175) eller via den romerske hær (Zachrisson 2014:183). Det ser jeg som lite sannsynlig; en romersk håndkvern brukt av soldatene ser helt annerledes ut - den er sylindrisk med vertikale rifler på ytterkanten, overliggerens overside er skålformet med markert kantlist, dreiepinnehullet er plassert horisontalt i ytterkanten og, ikke minst, kvernen har segl. Maleflatene er også riflet i et forseggjort mønster, ikke prikkhugget (Jodry 2011:88, fig. 2). Vi trenger derfor ikke å vende oss til Romerriket for å finne mulige opphavsområder. Hva som ga «støtet» til at dreiekvernen ble tatt i bruk, er et foreløpig ubesvart spørsmål. Det vi sikkert kan si, er at det ikke er knyttet til skiftet fra naken til agnekledd bygg. Det skjedde allerede i førromersk jernalder (Prøsch-Danielsen og Soltvedt 2011:figur 15).

Dreiekvernens opptreden i det sørvestnorske jordbrukssamfunnet må ha fortonet seg som en liten revolusjon. I stedet for å bruke mange timer hver dag på å male nok mel til husholdningens daglige konsum, kunne man male mel for flere dager på kort tid. Det betyr at arbeidskraft ble frigjort til andre oppgaver, og muligheten til å dyrke større arealer med korn åpnet seg. Dreiekvernen kan ha vært én komponent i jordbruksekspansjonen i eldre jernalder.

\section{Kvernsteinene i lokalsamfunnet}

Kartet på figur 7 gir et interessant bilde av spredningen av kvernsteinsfunnene i landsbyen på Forsandmoen. Funnene er begrenset til området på kartet, med unntak for kvernsteinen i bygning CLXXX (180), som ligger i en mindre samling bygninger omtrent $700 \mathrm{~m}$ fra områ- 
det med flest kvernsteiner. Det kan se ut som det fantes bare én dreiekvern i bruk til enhver tid i de første århundrene etter at dreiekverner var tatt i bruk. Hadde flere kverner vært i bruk samtidig, ville man kunne forvente flere funn av fragmenter. Det er selvfølgelig mulig at man kvittet seg med utslitte kverner på et annet sted som ikke er blitt undersøkt, eller at de ble knust til det ugjenkjennelige. Hvis det bare fantes én dreiekvern til enhver tid, må bruken av den nødvendigvis ha vært organisert. En mulighet er at man leverte sitt korn til maling, hvilket i tilfelle må ha betydd en betraktelig arbeidsbelastning for den husholdning som var i besittelse av kvernen. En annen mulighet er at de andre husholdningene kunne benytte dreiekvernen etter en bestemt turordning, og dermed ble kornmaling også en sosial aktivitet. De andre lokalitetene i analysen er tradisjonelle gårdsanlegg. Her ser det normale ut til å være at bare én kvern var i bruk til enhver tid. Unntaket er Ullandhaug, hvor ikke mindre enn 21 kvernsteiner ble funnet: tretten overliggere, fem underliggere og tre emner. Ikke en eneste ble funnet in situ. Antallet kvernsteiner er enestående, og det faktum at det finnes tre emner blant dem, peker mot at man produserte kvernsteiner på Ullandhaug.

Det er ikke uvanlig at man finner flere overliggere enn underliggere på en lokalitet (for eksempel Hauken og Anderson 2014a:cat. 78-80 fra Hodnafjell, Rennesøy, og cat. 81-84 fra Grønevoll tuft 1, Rennesøy), som kan tolkes på to måter. Enten var det vanlig å ha to overliggere til én underligger, overliggerne hadde da antagelig forskjellig funksjon (maling av forskjellige kornslag for eksempel), eller så ble overliggerne raskere utslitt enn underliggerne, som vanligvis er tykkere.

\section{Skubbekvern versus dreiekvern}

Skubbekverner har vært brukt i titusenvis av år i Egypt (Bloxam 2011), og brukes ennå i store deler av Afrika. Bruken av skubbekverner i Norge er nær knyttet til korndyrking ingen kvern, intet mel. Skubbekverner er ikke så tallrike i Rogaland som dreiekverner (62 registrert i samlingen pr. 31.12.2016), og de fleste er enten løsfunn eller funnet i stolpehull, eller som annet byggemateriale på boplasser. Det finnes kun én skubbekvern fra en sikkert datert primærkontekst - skubbekvernen fra Rugland, Hå kommune (S10260 m; Lindblom 1982), som ble funnet i 1979 snudd opp ned i kanten av et ildsted på en neolittisk boplass som var forseglet av en gravhaug fra jernalder. (Tilfeldigvis (?) ligger skubbekverner i forlatte neolittiske bygninger i Sveits opp ned i kanten av ildstedet; personlig kommunikasjon Timothy Anderson 2014.) Jordprøver ble tatt ut fra ildstedet, og i dem fant man de til da eldste kornene i Norge - 15 korn av naken bygg (Bakkevig 1982:37). En C14-datering av trekull fra ildstedet ga 2126-1693 f.Kr. (95,4 \% sannsynlighet, T-3450, 3550+/-70 BP). Kornene er ikke datert, den gang var det ikke mulig å datere så små mengder. Senere har man funnet enda eldre korn, som viser at korn (cerealia) ble dyrket i Sørvest-Norge fra ca. 2300 f.Kr. (for eksempel Bjørdal 2009:56), og pollenanalyser viser at korndyrkingen kan være enda eldre (Prøsch-Danielsen og Soltvedt 2011:133). Men det finnes fremdeles ingen eldre datert skubbekvern enn den fra Rugland i Rogaland.

Spørsmålet er om skubbekverner og dreiekverner var i bruk samtidig etter at dreiekvernen var tatt i bruk i det 2. århundre e.Kr. Det må selvfølgelig ha vært en overgangsperiode, men den var sannsynligvis ganske kort, kanskje en generasjon eller to, siden dreiekvernen både var mer effektiv og svært arbeidsbesparende. Mangelen på skubbekverner fra godt daterte primærkontekster kompliserer saken. Det er imidlertid ingen ting i det arkeologiske 
materialet som tyder på at skubbekverner og dreiekverner skulle ha vært brukt samtidig, slik det er blitt hevdet (Prøsch-Danielsen og Soltvedt 2011). På de 27 lokalitetene som inngikk i studien, forekommer skubbekverner bare i yngre kontekster (det vil si etter ca. 200 e.Kr.) som har spor etter eldre bosetning, og da som fragmenter og gjenbrukt som byggemateriale i yngre bygninger. Ullandhaug hus 3 er et slikt eksempel (se Hauken og Anderson 2014a:1011).

\section{Konklusjon}

Studien av dreiekvernene i Am, UiS viste at dreiekvernen ble tatt i bruk i annen halvdel av det 2. århundre e.Kr., det vil si minst 150 år tidligere enn antatt. Sammenlignet med skubbekvernen er den et svært arbeidsbesparende og effektivt verktøy til å male korn til mel. Derfor ble skubbekvernen raskt erstattet av dreiekvernen.

To forskjellige typer dreiekverner med undertyper ble identifisert i det forhistoriske materialet. De viste seg å være stort sett samtidige, unntatt overliggere av type I, som er den eldste, og overliggere type IIc, den eneste som fortsatt er i bruk i yngre jernalder. Kvernsteinene ble produsert lokalt av løsblokker i lokale bergarter; det finnes indikasjoner på at produksjon av kvernsteiner var et spesialisert håndverk og dermed en mulig lokal handelsvare. Kvernsteinsbrudd i områder uten granatglimmerskifer - som da potensielt kunne være fra eldre jernalder - er hittil ikke påvist i Rogaland. Kvernsteiner av granatglimmerskifer fra de store steinbruddene i Hyllestad og Saltdal forekommer bare i middelalderkontekster i Rogaland. De har seglmerker, og slike forekommer ikke på de forhistoriske kvernsteinene. Denne tekniske løsningen, som gjør det mulig å justere avstanden mellom over- og underligger, er helt nødvendig på store kvernsteiner i vann- og vindmøller. Når seglet ble tatt $\mathrm{i}$ bruk i Sørvest-Norge, er ikke kjent, men det skjedde sannsynligvis i løpet av vikingtid; dette er også et mulig tema for videre undersøkelser.

\section{Takk}

Takk til prosjektleder Gurli B. Meyer (NGU), Tom Heldal (NGU), Øystein J. Jansen (UiB) og Ann Meeks (Am, UiS) for heroisk innsats med bergartsbestemmelsene av kvernsteinene i samlingen ved Am, UiS, og resten av «kvernsteinsgjengen» involvert i The Millstone Project (ingen nevnt og ingen glemt). En særlig takk til Øystein J. Jansen for kartet figur 6, Theo Gil for kartet figur 1 og Eli-Christine Soltvedt for figur 8. Takk også til Trond Løken, som generøst ga tilgang til det upubliserte materialet på Forsandmoen og med stor tålmodighet svarte på alle spørsmål, liksom Olle H. Hemdorff for all informasjon om bosetningsspor i sin alminnelighet og Forsandmoen i særdeleshet. Takk til John Hines for hjelp med C14-statistikken og Bayes-modellen. Og sist, men ikke minst, en hjertelig takk til Timothy Anderson for alle illustrasjonene og for et særdeles godt samarbeid.

\section{Note}

1 En Bayes-modell er en statistisk modell som, svært enkelt forklart, gir mulighet i arkeologiske sammenhenger til å «snevre inn» tidsrammen for C14-dateringer i en sekvens med kjent begynnelse og slutt. 


\section{Summary}

\section{The introduction of the rotary quern in South West Norway}

This article presents the main findings of the work on early rotary querns in Rogaland, as part of The Norwegian Millstone Landscape research project initiated by the Norwegian Geological Survey (NGU). Querns are heavy and bulky, and usually considered an uninteresting class of objects. Despite their crucial role in subsistence and household economy, they have received very little attention by archaeologists. The present study concentrated, therefore, on the classification of querns, their production and raw materials, and their chronology. Two main types of upper and lower stones were identified in the prehistoric material. They were produced from erratic blocks collected on the surface, reflecting the local basement. Querns made from garnet mica schist by true bedrock extraction are only found in medieval and later contexts in Rogaland. Querns from the quarries in Hyllestad and Saltdal were identified. The chronological study revealed that the rotary quern had been introduced at least 150 years earlier than previously thought and rapidly replaced the saddle quern, and that its introduction was not directly connected to the introduction of new cereal crops.

\section{Litteratur}

Alonso, Natàlia, Francisco José Cantero, Rafel Jornet, Daniel López, Eva Montes, Georgina Prats og Sílvia Valenzuela

2014 Milling wheat and barley with rotary querns: The Ouarten women (Dahmani, Kef, Tunisia). I Seen through a millstone, redigert av Lotte Selsing, s. 11-30. AmS-Skrifter, vol. 24. Arkeologisk museum, Universitetet i Stavanger, Stavanger.

Bakkevig, Sverre

1982 Makrofossilanalyse. Saltvannsflotasjon av materiale fra Rugland på Jæren. I Faggrenser brytes. Artiklar tilegna Odmund Møllerop 7. desember 1982, redigert av Arnvid Lillehammer, s. 33-40. AmS-Skrifter, vol. 9. Arkeologisk museum i Stavanger, Stavanger.

Baug, Irene og Torbjørn Løland

2011 The millstone quarries in Hyllestad: an arena of research and education. I Bread for the People. The Archaeology of Mills and Milling. Proceedings of a Colloquium held in the British School at Rome 4th-7th November 2009, redigert av David Williams og David Peacock, s. 349-356. University of Southampton Series in Archaeology, vol. 3. BAR International series 2274. Archaeopress, Oxford.

Baug, Irene og Øystein J. Jansen

2014 Did the North Atlantic region constitute a market for quernstones from Norway during the Viking Age and the Middle Ages? I Seen through a millstone, redigert av Lotte Selsing, s. 245-255.

AmS-Skrifter, vol. 24. Arkeologisk museum, Universitetet i Stavanger, Stavanger.

Bergtröm, Liselotte

2007 Gräddat. Brödkultur under järnåldern i Mälardalen. Theses and Papers in Scientific Archaeology, vol. 9. Stockholms Universitet, Stockholm.

Bjørdal, Even

2009 Arkeologisk utgraving av toskipa langhus frå overgangen yngre steinalder - eldre bronsealder og graver frå vikingtid og yngre jernalder på Frøyland. Frøyland gnr. 28, bnr. 1 mfl. Oppdragsrapport B 2009/4. Arkeologisk Museum, Universitetet i Stavanger.

2016 Late Iron Age settlement evidence from Rogaland. I The Agrarian Life of the North 2000 BC - AD 1000: studies in rural settlement and farming in Norway, redigert av Frode Iversen og Håkan Petterson, s. 241-274. Portal forlag, Kristiansand. 
Bloxam, Elizabeth

2011 Visualising the invisible: re-discovering the ancient grinding stone quarries at the Aswan West Bank, Egypt. I Bread for the People. The Archaeology of Mills and Milling. Proceedings of a Colloquium held in the British School at Rome 4th-7th November 2009, redigert av David Williams og David Peacock, s. 45-53. University of Southampton Series in Archaeology, vol. 3. BAR International series 2274. Archaeopress, Oxford.

Børsheim, Ragnar og Eli-Christine Soltvedt

2002 Gausel: utgravingene 1997-2000. AmS-Varia, vol. 39. Arkeologisk museum i Stavanger, Stavanger.

Dahl, Johanne Margrete

1986 Kvernsteinene på Ullandhaug. Frá haug ok heiðni 1986 (1):4-7.

Green, Chris

2011 Hertfordshire Puddingstone querns - working with a difficult rock. I Bread for the People. The Archaeology of Mills and Milling. Proceedings of a Colloquium held in the British School at Rome 4th-7th November 2009, redigert av David Williams og David Peacock, s. 123-130. University of Southampton Series in Archaeology, vol. 3. BAR International series 2274. Archaeopress, Oxford.

Grenne, Tor, Gurli B. Meyer og Tom Heldal

2014 Unravelling the history of a complex millstone quarry landscape: Tolstadkvernberget, South Norway. I Seen through a millstone, redigert av Lotte Selsing, s. 209-226. AmS-Skrifter, vol. 24. Arkeologisk museum, Universitetet i Stavanger, Stavanger.

Grenne, Tor, Gurli B. Meyer, Tom Heldal, Øystein J. Jansen, og Torbjørn Løland

2014 Technological development in millstone quarrying through the Middle Ages: the Salten quarries, Northern Norway. I Seen through a millstone, redigert av Lotte Selsing, s. 227-244. AmSSkrifter, vol. 24. Arkeologisk museum, Universitetet i Stavanger, Stavanger.

Grieg, Sigurd

1928 Kongsgaarden. Osebergfundet, bind II, redigert av Anton Wilhelm Brøgger og Håkon Shetelig.

Hatt, Gudmund A.W. Brøggers boktrykkeri A/S, Universitets Oldsakssamling, Oslo.

1930 En brandtomt af et Jernalderhus paa Mors. Aarbøger for Nordisk Oldkyndighed og Historie 1930:83-118.

Hauken, Åsa Dahlin og Timothy Anderson

2014a Collection Report: Rotary Querns in the Museum of Archaeology, University of Stavanger. Report number: 2014.002. Project Millstone - The Norwegian Millstone Landscape. NGU, Trondheim. Elektronisk dokument, http://www.ngu.no/upload/Publikasjoner/ Rapporter/2014/2014_002.pdf, besøkt 25. januar 2018.

2014b Samlingsrapport: Manual til registringsskjema dreiekvern. Guide to the Rotary Quern Registration Form. Report number: 2014.008. Project Millstone - The Norwegian Millstone Landscape. NGU, Trondheim. Elektronisk dokument, http://www.ngu.no/upload/Publikasjoner/ Rapporter/2014/2014_008.pdf, besøkt 25. januar 2018.

Heldal, Tom og Gurli B. Meyer

2011 The rise and fall of the Hyllestad millstone quarry landscape, Western Norway. I Bread for the People. The Archaeology of Mills and Milling. Proceedings of a Colloquium held in the British School at Rome 4th-7th November 2009, redigert av David Williams og David Peacock, s. 325-339. University of Southampton Series in Archaeology, vol. 3. BAR International series 2274. Archaeopress, Oxford.

Jodry, Florand

2011 First century querns of the Roman army in the light of modern texts. I Bread for the People. The Archaeology of Mills and Milling. Proceedings of a Colloquium held in the British School at Rome 4th-7th November 2009, redigert av David Williams og David Peacock, s. 85-91. 
University of Southampton Series in Archaeology, vol. 3. BAR International series 2274.

Archaeopress, Oxford.

Jørgensen, Anne Bloch

1990 Kværn- og knusesten: En undersøkelse af materialet fra Vorbasse og Nørre Snede med særlig henblik på jernalderdreiekværnen. Upublisert hovedfagsspeciale i forhistorisk arkæologi. Århus universitet, Århus.

2002 Investigations of Danish rotary querns from the Iron Age: archaeological evidence and practical experiments. I Moudre et broyer: L'interprétation fonctionelle de l'outilage de mouture et de broyage dans la préhistoire et l'Antiquité: actes de la Table Ronde internationale, ClermontFerrand, 30 nov. -2 déc. 1995, redigert av Hara Procopiou og René Treuil, s.183-196. II. Archéologie et histoire: du Paléolithique au Moyen Âge. CTHS, Paris.

Lindblom, Inge

1982 Del 1 Rugland - en sen-neolittisk boplass på Jæren, Sørvest-Norge. I Faggrenser brytes. Artikler tilegna Odmund Møllerop 7. desember 1982, redigert av Arnvid Lillehammer, s. 15-31.

AmS-Skrifter, vol. 9. Arkeologisk museum i Stavanger, Stavanger.

Løken, Trond

1996 Forsandmoen, Forsand kommune, Rogaland. I Maskinell flateavdekking og utgravning av forhistoriske jordbruksboplasser - en metodisk innføring, redigert av Trond Løken, Lars Pilø og Olle Hemdorff, s. 69-78. AmS-Varia, vol. 26. Arkeologisk museum i Stavanger, Stavanger.

2001 Oppkomsten av den germanske hallen - Hall og sal i eldre jernalder i Rogaland. Viking 64:49-86.

I trykk The Bronze Age and Early Iron Age Settlement at Forsandmoen in Rogaland. AmS-Skrifter. Arkeologisk museum, Universitetet i Stavanger, Stavanger.

Müller, Sophus

1907 Nye Fund og Iagttagelser fra Sten-, Bronze- og Jernalderen. Omdreiende Kværne. Aarbøger for Nordisk Oldkyndighed og Historie 1907:142-148.

Myhre, Bjørn

1992 Funderinger over Ullandhaugs bosetningshistorie. I Gammel gård gjenoppstår: fra gamle tufter til levende museum, redigert av Anne Kari Skår, s. 46-68. AmS-Småtrykk, vol. 26. Arkeologisk museum i Stavanger, Stavanger.

Myhre, Bjørn og Ingvild Øye

2002 Norges landbrukshistorie, Band I. 4000 f.Kr. -1350 e.Kr. Jorda blir levevei. Det Norske Samlaget, Oslo.

Peacock, David

2013 The stone of life. Querns, mills and flour production in Europe up to c. AD 500. Southampton Monographs in Archaeology New Series, vol. 1. Highfield Press, Southampton.

Peacock, David og Lynn Cutler

2011 The earliest rotary querns in southern England. I Bread for the People. The Archaeology of Mills and Milling. Proceedings of a Colloquium held in the British School at Rome 4th-7th November 2009, redigert av David Williams og David Peacock, s. 77-80. University of Southampton Series in Archaeology, vol. 3. BAR International series 2274. Archaeopress, Oxford.

Petersen, Jan

1916 Gravplassen fra Store-Dal i Skjeberg. Norske Oldfunn, vol. 1. Universitetets Oldsaksamling, Kristiania.

1933 Gamle gårdsanlegg $i$ Rogaland fra forhistorisk tid og middelalder. Instituttet for sammenlignende kulturforskning, Serie B: Skrifter, vol. 23. Aschehoug, Oslo.

1936 Gamle gårdsanlegg $i$ Rogaland. Fortsettelse. Instituttet for sammenlignende kulturforskning, Serie B: Skrifter, vol. 31. Aschehoug, Oslo.

1951 Vikingtidens redskaper. Skrifter utgitt av Det Norske Videnskaps-Akademi i Oslo, II. HistoriskFilosofisk Klasse 1951(4). Dybwad, Oslo. 
Prøsch-Danielsen, Lisbeth og Eli-Christine Soltvedt

2011 From Saddle to Rotary Hand Querns in South-Western Norway and the Corresponding Crop Plant Assemblages. Acta Archaeologica 82:129-162.

Reimer, Paula J., Edouard Bard, Alex Bayliss, J. Warren Beck, Paul G. Blackwell, Christopher Bronk

Ramsey, Caitlin E. Buck, Hai Cheng, R. Lawrence Edwards, Michael Friedrich, Pieter M. Grootes,

Thomas P. Guilderson, Haflidi Haflidason, Irka Hajdas, Christine Hatté, Timothy J. Heaton,

Dirk L. Hoffmann, Alan G. Hogg, Konrad A. Hughen, K. Felix Kaiser, Bernd Kromer, Sturt W. Manning,

Mu Niu, Ron W. Reimer, David A. Richards, E. Marian Scott, John R. Southon, Richard A. Staff,

Christian S. M. Turney og Johannes van der Plicht

2013 IntCal13 and Marine13 Radiocarbon Age Calibration Curves 0-50,000 Years cal BP. Radiocarbon 55(4):1869-1887.

Watts, Susan

2014 The symbolism of querns and millstones. I Seen through a millstone, redigert av Lotte Selsing, s. 51-64. AmS-Skrifter, vol. 24. Arkeologisk museum, Universitetet i Stavanger, Stavanger.

Wefers, Stefanie

2011 Still using your saddle quern? A compilation of the oldest known rotary querns in Western Europe. I Bread for the People. The Archaeology of Mills and Milling. Proceedings of a Colloquium held in the British School at Rome 4th-7th November 2009, redigert av David Williams og David Peacock, s. 67-76. University of Southampton Series in Archaeology, vol. 3. BAR International series 2274. Archaeopress, Oxford.

Zachrisson, Torun

2004 The holiness of Helgö. I Excavations at Helgö XVI. Exotic and Sacral Finds from Helgö, redigert av Helen Clarke og Kristina Lamm, s. 143-175. Kungl. Vitterhets historie och antikvitets akademien, Stockholm.

2014 Rotary querns and bread - A social history of Iron Age Sweden. I Seen through a millstone, redigert av Lotte Selsing, s. 181-191. AmS-Skrifter, vol. 24. Arkeologisk museum, Universitetet i Stavanger, Stavanger. 